\title{
Development of Chemical Compositions of Artificial Cement Stone Using Coal and Waste Rock
}

\author{
Tatiana Cherkasova ${ }^{1}$, Viktor Tatsienko ${ }^{1}$, Anastasia Tikhomirova ${ }^{1}$, Elizaveta Cherkasova $^{1}$, \\ Oleg Dormeshkin ${ }^{2}$ \\ ${ }^{1}$ T.F. Gorbachev Kuzbass State Technical University, 650000, Russian Federation \\ ${ }^{2}$ Belarusian State Technological University, Belarus
}

\begin{abstract}
The use of cement support is being currently introduced during drivage. The correct, competent choice of grouting mortar formulations according to mining and geological conditions and their timely use can reduce unproductive labor, time and money, increase productivity and timely commissioning of the mine. An analysis of chemical composition of grouting mixtures using coal and waste rock required for their production was carried out using IR spectroscopic, chemical and X-ray fluorescence analyzes.
\end{abstract}

\section{Introduction}

The correct, competent choice of grouting mortar formulations according to mining and geological conditions and their timely use can reduce unproductive labor, time and money, increase labor productivity and timely commissioning of the mine [1-8].

Cement, gypsum, lime, and synthetic resins are most often used as binders in the grouting practice. The compositions and properties of grouting mixtures are very diverse and are selected depending on their purpose, in accordance with which the requirements for the selected grouting mixture and cement obtained by hardening should be presented. When supporting mine workings with cement, the most important requirements are the strength of cement and the high curing rate. Synthetic resins that are produced outside the Russian Federation are often used as auxiliary reagents, which significantly increase the cost of grouting mixtures. When driving mine workings through rock, waste is generated in the form of waste rock and, in part, coal, which leads to significant economic costs for hoisting the rock mass to the surface and further storage in dumps, so the aim of the work was to develop engineering measures for supporting the mine workings with cement applying chemical methods and using rocks.

To achieve this goal, the project solved the following tasks:

1. Carrying out a technical analysis of S.M. Kirov coal mine (SUEK-Kuzbass JSC);

2. Studying the qualitative and quantitative composition of the S.M. Kirov coal mine waste dumps;

3. Studying the processes for the preparation of grouting mixtures due to the use of various chemical reagents in a mixture with S.M. Kirov coal mine rock dumps. 


\section{Research methods}

In the framework of the work, it was necessary to find out whether there are mineral binders in coal and waste rock of the mine, as well as to determine their quantity and whether it is sufficient for grouting, or if additional components are required. In this regard, IR spectroscopic, chemical, and X-ray fluorescence ultimate analyzes were carried out to determine the content of $\mathrm{Ca}^{2+}, \mathrm{Mg}^{2+}$ ions of coal and rock.

IR spectroscopic analysis was performed by means of Agilent Cary 630 FTIR spectrometer in the range of 4000-650 $\mathrm{cm}^{-1}$.

$100 \mathrm{~g}$ of the rock was ground and leached with hot concentrated nitric acid for 12 hours with stirring. Then the resulting solution was filtered and neutralized to a $\mathrm{pH}$ of 6 with an ammonia solution, and iron (III) hydroxide precipitated. Further, the solution was again filtered and analyzed for calcium and magnesium.

For the joint determination of $\mathrm{Ca}^{2+}$ и $\mathrm{Mg}^{2+}$ ions, $100 \mathrm{~cm}^{3}$ of the analyzed solution (V samples) were weighed with a pipette and transferred it to a conical titration flask with a capacity of $250 \mathrm{~cm}^{3} .5 \mathrm{~cm}^{3}$ of ammonium buffer mixture and 7-8 drops of a solution of black chromogen indicator were added to the selected sample. Then the prepared sample was titrated with disodium dihydrogen ethylenediaminetetraacetate solution until the winered color turned to blue (with a greenish cast).

When determining the content of $\mathrm{Ca}^{2+}$ ions, the same volume of the analyzed solution as in the previous analysis $\left(\mathrm{V}_{\text {sample }}=100 \mathrm{~cm}^{3}\right)$ was weighed with a pipette, transferred to a conical titration flask with a capacity of $250 \mathrm{~cm}^{3} .5 \mathrm{~cm}^{3}$ of a $20 \% \mathrm{NaOH}$ solution was added to the flask; $30-40 \mathrm{mg}$ of a mixture of murexide with sodium chloride was added at the tip of a spatula. The sample was titrated with disodium dihydrogen ethylenediaminetetraacetate solution until the red color turned to violet.

A coal sample was preliminarily reduced to ash, and then an analysis was performed according to the method described above.

$\mathrm{X}$-ray fluorescence ultimate analysis was carried out in the range of determined concentrations: from $0.0001 \%$ to $100 \%$ using a SPECTROSCAN MAKC-GV wave dispersive X-ray fluorescence spectrometer.

\section{General results}

In the low-frequency region (up to $1000 \mathrm{~cm}^{-1}$ ), the vibration spectrum of a number of groups of aromatic, aliphatic and naphthenic structures is recorded by the IR spectrum of coal. Vibrations caused by the mineral component of coal are detected in the spectra. The frequency of stretching vibrations of $1037 \mathrm{~cm}^{-1}$ is associated with the presence of the Si-O group. The band with a maximum of $1215 \mathrm{~cm}^{-1}$ is due to vibrations of oxygen-containing groups of ethers - C-OR. An intense peak of deformation vibrations of aliphatic structures at $1444 \mathrm{~cm}^{-1}$ is observed in the spectrum. The band of $1584 \mathrm{~cm}^{-1}$ is due to stretching vibrations of $\mathrm{C}-\mathrm{C}$ bonds of the aromatic ring. The region of stretching vibrations of $\mathrm{CH}$ bonds in aliphatic and naphthenic fragments is recorded in the range of $2856-2918 \mathrm{~cm}^{-1}$. A group of bands in the region of $1874-2396 \mathrm{~cm}^{-1}$ characterizes the presence of amines in coal.

The IR spectrum of the rock clearly shows the band of $1003 \mathrm{~cm}^{-1}$ associated with the presence of a large amount of silicates in the sample.

The content of calcium and magnesium ions determined by the chemical method in 100 $\mathrm{g}$ of rock was $1.7 \mathrm{~g}$ and $1.6 \mathrm{~g}$, respectively. The amount of calcium and magnesium ions in $100 \mathrm{~g}$ of ash was $2.5 \mathrm{~g}$ and $0.9 \mathrm{~g}$, respectively.

Contents of the main mineral components in coal and rock of S.M. Kirov coal mine, determined by X-ray fluorescence are shown in Table 1. 
Table 1. Contents of the main mineral components in coal and rock of S.M. Kirov coal mine.

\begin{tabular}{|l|l|l|l|l|l|l|}
\hline \multirow{2}{*}{ Sample } & \multirow{2}{*}{$\mathbf{A}^{\mathbf{d}}$} & \multicolumn{5}{|l|}{ The chemical composition of the ash } \\
\cline { 3 - 7 } & & $\mathbf{S}_{\mathbf{i}} \mathbf{O}_{2}$ & $\mathbf{S O}_{3}$ & $\mathbf{A l}_{2} \mathbf{O}_{3}$ & $\mathbf{F e}_{2} \mathbf{O}_{3}$ & $\mathbf{C a O}$ \\
\hline & $\%$ & $\%$ & $\%$ & $\%$ & $\%$ & $\%$ \\
\hline Rock & 85,7 & 67,53 & 0,23 & 21,61 & 2,93 & 0,26 \\
\hline Coal & 4,9 & 25,92 & 10,39 & 12,77 & 13,36 & 22,45 \\
\hline & $\mathrm{MgO}$ & $\mathrm{K}_{2} \mathrm{O}$ & $\mathrm{Na}_{2} \mathrm{O}$ & $\mathrm{MnO}$ & $\mathrm{TiO}_{2}$ & $\mathrm{P}_{2} \mathrm{O}_{5}$ \\
\hline & $\%$ & $\%$ & $\%$ & $\%$ & $\%$ & $\%$ \\
\hline Rock & 1,39 & 3,20 & 1,30 & 0,02 & 1,06 & 0,18 \\
\hline Coal & 10,69 & 0,98 & 1,79 & 0,07 & 0,59 & 0,13 \\
\hline
\end{tabular}

The authors prepared grouting mixtures based on:

1. Waste rock using lime and lime mortar.

2. Waste rock using "water glass".

3. Waste rock using burnt lime and soda ash.

4. Waste rock using plaster.

5. $70 \%$ coal and $30 \%$ waste rock mixtures using plasticizers (lime putty - $\mathrm{Ca}(\mathrm{OH})_{2}$, polyvinyl-acetate adhesive, silicate glue, laundry soap and cemFIX plasticizer).

When preparing the mixture 1 by quartering and subsequent sieving to a particle size of 1.2-2 mm, a sample of rock weighing $5 \mathrm{~g}$ was taken. A saturated solution of $\mathrm{Ca}(\mathrm{OH})_{2}$ was added to the sample (concentration at $20^{\circ} \mathrm{C}$ is $1.56 \mathrm{~g} / \mathrm{dm}^{3}$ ). Every 10 minutes for 2 hours a visual control was carried out to monitor the change in the appearance of the mixture. After 2 hours, the suspension did not thicken; the mixture thickened after 12 hours.

$5 \mathrm{~g}$ of burnt quicklime $(\mathrm{CaO})$ was added to the ground rock sample $(5 \mathrm{~g})$. The mixture hardened within 30 minutes, but after 12 hours exposure to air it became brittle and began to crack.

A rock sample with a mass of $11.4 \mathrm{~g}$ was prepared; $11.5 \mathrm{~g}$ of burnt quicklime was added. After 5 minutes, the mixture was very hot and thickened with the outside crust, but remained soft inside. After exposure for 12 hours, the composition dried out and began to crack.

$1 \mathrm{ml}$ of "liquid glass" $\left(\mathrm{Na}_{2} \mathrm{SiO}_{3}\right)$ was added to $10 \mathrm{~g}$ of a mixture 2 of 1.2-2 mm size waste rock particles. After 7 minutes, the composition set, but the mass remained soft, i.e. mobile under mechanical action. After 13 and 30 minutes the suspension did not thicken. Then another $6 \mathrm{ml}$ of "liquid glass" was added to the mixture. After 2 hours, the mass was completely thickened. After 24 hours, the mixture became very strong in bending and compression.

When $11.4 \mathrm{~g}$ of rock, $5.5 \mathrm{~g}$ of $\mathrm{Na}_{2} \mathrm{CO}_{3}$ (chemically pure), $11.5 \mathrm{~g}$ of $\mathrm{CaO}$ and $22 \mathrm{ml}$ of water (mixture 3 ) were mixed, a slight heating occurred, binding started inside the sample mass, and liquid remained on the surface. After 20,30 and 50 minutes the suspension did not thicken. Another $10 \mathrm{~g}$ of $\mathrm{Na}_{2} \mathrm{CO}_{3}$ being added, no changes occurred.

AXTON gypsum for internal construction work was used for mixture 4. $10.19 \mathrm{~g}$ of gypsum was mixed (1:1) with $10.31 \mathrm{~g}$ of waste rock; $10 \mathrm{ml}$ of water was added (in terms of 0.7-1.2 1 of water per $100 \mathrm{~kg}$ of gypsum). After 15 minutes, the mixture hardened almost completely on the surface, but remained moist in the depths.

A mixture (2:1) of $20.34 \mathrm{~g}$ of rock and $10.34 \mathrm{~g}$ of gypsum was prepared; $10 \mathrm{ml}$ of water was added. After 5 minutes, the water has already "bound", after 8 minutes the mass has hardened on the surface, and remained moist in the depths. 
$10 \mathrm{ml}$ of water was added to a mixture (4:1) of $20.38 \mathrm{~g}$ of waste rock and $5.09 \mathrm{~g}$ of gypsum. After 30 minutes, the mass hardened on the surface, but remained moist in depth.

After curing all samples for 12 hours, the mass completely dried out, but became brittle.

Mixture series 5 was prepared using $30 \mathrm{~g}$ of coal and $10 \mathrm{~g}$ of waste rock; $40 \mathrm{~g}$ of gypsum and $40 \mathrm{ml}$ of water were added. When water was added, coal dust was collected on the surface. After 7 minutes, the mass froze, and liquid remained on the surface. After 13 minutes, almost complete solidification occurred. After curing for 12 hours, the mixture began to crumble a little.

When left to stand undisturbed for 30 minutes, a mixture of $10 \mathrm{~g}$ of coal, $10 \mathrm{~g}$ of gypsum and $10 \mathrm{ml}$ of water thickened, but the mass remained very brittle.

$4 \mathrm{ml}$ of polyvinyl-acetate adhesive was added to a mixture consisting of $30 \mathrm{~g}$ of coal, 10 $\mathrm{g}$ of waste rock, $40 \mathrm{~g}$ of gypsum and $40 \mathrm{ml}$ of water. After an hour, the suspension thickened, but liquid remained on the surface of the mixture. After 12, 18, 24 hours, the mixture remained wet. Then it froze, but became brittle.

A mixture of $30 \mathrm{~g}$ of coal and $10 \mathrm{~g}$ of waste rock was prepared; $40 \mathrm{~g}$ of gypsum and 40 $\mathrm{ml}$ of water were added, then $4 \mathrm{ml}$ of laundry soap was added. After an hour of exposure, the mixture nearly did not thicken in volume. After 12, 18, 24, 48, 72 hours, the mixture remained moist.

$40 \mathrm{~g}$ of gypsum and $40 \mathrm{ml}$ of water were added to a mixture of $30 \mathrm{~g}$ of coal and $10 \mathrm{~g}$ of waste rock; then $4 \mathrm{ml}$ of silicate glue was added. The mass hardened within 5 minutes and became hard to compress, but more brittle to bend.

$4 \mathrm{ml}$ of lime putty was added to a mixture of $30 \mathrm{~g}$ of coal and $10 \mathrm{~g}$ of waste rock, $40 \mathrm{~g}$ of gypsum and $40 \mathrm{ml}$ of water. The mass completely hardened in 13 minutes and acquired the same strength as that in the experiment with silicate glue.

After preparing a mass consisting of $30 \mathrm{~g}$ of coal, $10 \mathrm{~g}$ of waste rock, $40 \mathrm{~g}$ of gypsum and $40 \mathrm{ml}$ of water, $1 \mathrm{ml}$ of hardening agent, cemFIX superplasticizer, was added to the mixture. The mixture solidified after 10 minutes. The mass has become strong enough to crush, but not strong enough to bend.

\section{Conclusion}

Thus, the analysis shows that there are few mineral binders in the samples. Although there is a lot of calcium oxide in coal ash, taking into account the ash content of coal, when counting, this amount is insufficient for cement supporting of the mine workings and it is necessary to introduce an additional amount of binding components to obtain cement and waste rock grouting mixtures.

According to research, a mixture prepared on the basis of $70 \%$ coal and $30 \%$ waste rock with the addition of gypsum and additives that increase workability in a ratio of $1: 1$ has the greatest strength.

- Silicate glue being added; the mixture hardened in 5 minutes.

- Lime putty being added; the mixture hardened in 13 minutes.

- CemFIX accelerating agent being added; the mixture hardened in 10 minutes (at a consumption of cemFIX 4 times less than other additives).

It is necessary to continue research on the preparation of grouting mixtures having an optimal curing time and greater strength. 


\section{References}

1. R. Zeng, X. Zhuang, N. Koukouzas, W. Xu, Int. J. Coal Geol, 61, 833 (2005)

2. R. N. Peres, E. S. F. Cardoso, M. F. Montemor, H. G. Melo, A. V. Benedetti, P. H. Suegama, Surf Coat Technol (Part B), 303, 372 (2016)

3. F. Khelifa, M-E. Druart, Y. Habibi, F. Bénard, P. Leclère, M. Olivier, P. Dubois, Prog Org Coat, 76, 900 (2013)

4. Y. Chen, T. Nishiyama, M. Terada, Y. Iwamoto, Engineering Geology, 56, 395 (2000)

5. Y. Huang, L. Wang, Engineering Geology, 204, 23 (2016)

6. M. Sonebi, Journal of Materials in Civil Engineering. 22 (4), 332 (2010)

7. K. Binnemans, P. T. Jones, B. Blanpain, T. Van Gerven, Y. Pontikes, Journal of Cleaner Production, 99, 17 (2015)

8. B. N. Kumar, S. Radhika, M. L. Kantam and B. R. Reddy, J. Chem. Technol. Biot., 86 (4), $562(2011)$

9. L. S. Wang, Z. Q. Long, X. W. Huang, Y. Yu, D. L. Cui and G. C. Zhang, Hydrometallurgy, 101 (1-2), 41 (2010)

10. P. M. Reza, P. Norouzi, H. Rashedi, M. R. Ganjali, J Appl Electrochem, 40, 1593 (2010)

11. Kashiwakura Shunsuke, Kumagai Yuichi, Kubo Hiroshi, Wagatsuma Kazuaki, Open Journal of Physical Chemistry, 3, 69 (2013)

12. H. El-Didamony, M. M. Ali, N. S. Awwad, M. M. Fawzy and M. F. Attallah, J. Radioanal. Nucl. Chem., 291, (3), 907 (2012)

13. H. Güllü, Construction and Building Materials, 93, 891 (2015)

14. Franus Wojciech, Małgorzata M. Wiatros-Motyka, Magdalena Wdowin, Environmental Science and Pollution Research, 22, 9464 (2015)

15. C. N. Lange, I.M. C. Camargo, A. M. G. M. Figueiredo, L. Castro, M. B. A. Vasconcellos, R. B. Ticianelli, Journal of Radioanalytical and Nuclear Chemistry, 311, 1235 (2017) 